Ramón VINYEs, Entre sanbas y bananas. Editorial Norma: Bogotá, 1986. (Traducción de Montserrat Ordóñez.)

Para muchos lectores de la literatura latinoamericana, Ramón Vinyes ocupa un lugar casi mítico en la historia de nuestras letras. Gabriel García Márquez lo inmortalizó en sus Cien años de soledad con el apodo del «sabio catalán». Sin embargo, poco se sabe del Ramón Vinyes escritor catalán y radicado por muchos años en la ciudad de Barranquilla, Colombia, donde participó activamente organizando tertulias en su librería.

Ramón Vinyes deja una profunda huella en la historia de la literatura colombiana contemporánea, ya que es este «sabio catalán» quien trae a Barranquilla a los escritores del viejo mundo, y así, integrantes del destacado grupo de Barranquilla entre ellos: Bernardo Restrepo Maya, Alfonso Fuenmayor, Germán Vargas y posteriormente Gabriel García Márquez, comparten con y por medio de Vinyes a los autores europeos de la época.

Vinyes, nacido en Barcelona en 1882, permanece por largas temporadas en Colombia, regresando también a Barcelona. Sin embargo, su regreso definitivo a Barranquilla resulta infructuoso y éste muere en Barcelona, en 1952, a la edad de setenta años.

El cuento fue un género poco desarrollado por Vinyes y se le conoce más como dramaturgo y ensayista. Sin embargo, sus historias, publicadas por primera vez en español bajo la excelente traducción de Montserrat Ordóñez, son una verdadera joya que nos permite re-descubrir y re-leer a este fascinante personaje.

Enire sambas y bananas es una colección de seis cuentos, cuya nota mayor destaca un profundo sentido del humor, como también una nostalgia por el territorio perdido, ya sea Barcelona o Colombia. A través de estos relatos observamos, con nitidez, una interesante mezcla en la narrativa de Vinyes, que fluctúa entre el contexto europeo de sus escritos como también el esplendor de los escenarios tropicales del paisaje de Barranquilla. Esa mezcla entre la Europa nostálgica y el trópico salvaje, a veces desmedido, son una de las constantes de Entre sambas y bananas, como, por ejemplo, «La Pascua de Resurrección», uno de los cuentos más logrados de la colección. En esta historia observamos cómo el trópico, con sus habitantes, aparece cargado de una atmósfera sensual alocada y extravagante. Una viuda de ancestros europeos encuentra su amor, su pascua de resurrección, junto a Totai, un indio de las selvas amazónicas del Ecuador. El humor, la abun- 
dancia de la escenografía tropical, son algunos de los elementos predominantes: «Dicen que todo acto de locura, por noble que sea y a pesar de las posibilidades que tenga de poderse razonar, puede traer consecuencias graves. $i Y$ es cierto!» (p. 11).

El último cuento de la colección, «Dietario a saltos», también ejemplifica algunos aspectos característicos de Vinyes, como la nostalgia de un europeo lejos de su país, de su pueblo en los Pirineos, y también la nostalgia de un vagabundo trapecista en un circo itinerante.

Entre sambas y bananas es una colección amena, bella e interesante, donde por medio de un lenguaje coloquial y poético el lector descubre la magia del trópico visto por un narrador europeo, un sabio catalán traducido por primera vez al idioma español.

\section{Wellesley College}

MARJoRIE AgOSIN

FERnANdo BuRgos, La novela moderna hispanoamericana. Madrid: Editorial Orígenes (Colección Discursorígenes), 1985.

Estudio lúcido y de estilo vibrante, que propone redefinir la novela hispanoamericana de nuestro siglo a partir de una comprensión dialéctica, no lineal, de la evolución de la historia literaria.

E1 primer capítulo explora y sintetiza, desde una postura crítica, el origen y fundamentaciones teóricas del concepto de modernidad, y en ese contexto redefine el modernismo hispanoamericano a la luz de las contradicciones y límites de la ya clásica disputa sobre sus relaciones con la estética naturalista y el positivismo filosófico. El autor apoya su tesis en reflexiones teóricas que van de Federico de Onís a Ivan Schulman, de Octavio Paz a Ricardo Gullón y que comparten el propósito de rescatar la continuidad operacional entre modernismo y modernidad (vanguardia y neo-vanguardia van implícitos en el último término). Quedan descartadas las categorías positivistas que regimentaban las clasificaciones según géneros, escuelas, generaciones o períodos, así como las simplificaciones causalistas o deterministas, y en su lugar se propone confirmar la fluidez y multidimensionalidad del modernismo como clave para un acercamiento al problema por vías de la actitud crítica que lo fundamenta.

E1 segundo capítulo se aboca a definir el concepto global de modernidad, dentro del cual Modernismo, Vanguardia y Neo-Vanguardia devienen «modos» complementarios, en mutua conjunción y disyunción. Frente al concepto monológico del discurso a que nos acostumbraran la obra y la crítica clásicas, la modernidad impone formas dialogísticas o corales que burlan las barreras generacionales y cronológicas, para abrir un amplio y resonante movimiento intertextual. Paul de Man e Ihab Hassan prestan aquí a Burgos el apoyo teórico para explicar la función de la contradicción, el juego y el silencio en la nueva actitud escritural. Dentro de la modernidad, tanto las obras como la crítica han de recuperar la interrogación como elemento constitutivo esencial. Actitud poliédrica, discontinua y fragmentaria por definición, la modernidad no puede ser atrapada en un concepto coherente precisamente porque su signo escapa toda imposición categorial, como sugiere Baudrillard. 